\title{
Residual Efficacy of Certain Insecticides for Protecting Grain Stores from Infestation of Stored Product Insects
}

\author{
Saad, A. S. A., E. H. M. Tayeb, O. A. Zaghloul and A. A. Abdulghani \\ Plant Protection Dept., Fac. Agric. (Saba Basha), Alex. Univ., P.O Box 21531-Bolkly, \\ Alex., Egypt
}

\begin{abstract}
Pesticides are relatively inexpensive and easy tool that can be used and applied for controlling stored-products insects attacking grain elevators, grain stores, flours mills and feed mills. Certain contact insecticides of low mammalian can be applied and sprayed in these stores of grains before or during storage to protect them from insect pests or to control established infestations. Four insecticides (lambda-cyhalothrin [Lambada- Magic ${ }^{\circledR} 5 \%$ EC], primiphos- methyl [Actellic ${ }^{\circledR} 50 \%$ EC], chlorpyrifos [Magic-phos ${ }^{\circledR} 48 \%$ EC] and spinetoram [Radiant ${ }^{\circledR} 12 \%$ SC]) were tested against adults of Sitophilus oryzae (L.) and Tribolium castaneum (Herbst), using direct contact application. The response varied with chemical insecticide, insect species and exposure time. Filter paper diffusion method at different doses was used for assaying the different tested insecticides. Spinetoram was highly toxic against $T$. castaneum after 24 and $48 \mathrm{hrs}$ of exposure. Lambda-cyhalothrin was highly toxic against $T$. castaneum followed by spinetoram; chlorpyrifos and primiphos-methyl after the period of exposure of $72 \mathrm{hrs}$. Nevertheless, it could be noticed that the toxic effect of spinetoram $\left(\mathrm{LC}_{50}=4.12 \mathrm{ppm}\right)$ was close to that of lambda-cyhalothrin $\left(\mathrm{LC}_{50}=3.28 \mathrm{ppm}\right)$ after exposure period of 72 hrs. Spinetoram was highly toxic against $S$. oryzae followed by chlorpyrifos, and primiphos-methyl after 24 and $48 \mathrm{hrs}$. Spinetoram was also highly toxic against $S$. oryzae followed by chlorpyrifos, lambda-cyhalothrin and primiphos-methyl after $72 \mathrm{hrs}$. The results indicated that spinetoram as a novel insecticide is highly toxic to both the red flour beetle $T$. castaneum and the rice weevil S. oryzae. Implications of these results for stored product insects' management programs would be beneficial.
\end{abstract}

Keywords: Tribolium castaneum, Sitophilus oryzae, lambda- cyhalothrin, primiphos- methyl, chlorpyrifos, spinetoram, Toxicity index, Relative potency

\section{INTRODUCTION}

Annual post-harvest losses resulting from insect damage, microbial deterioration and other factors such as humidity, temperature, aeration and cleanliness of the bulk storage, are estimated to be $10-25 \%$ of production worldwide (Mohan and Fields, 2002). However, insects are the main problem in stored grain because they reduce the quantity and the quality of grains (Madrid et al., 1990).

The red flour beetle Tribolium castaneum (Herbst.) (Coleoptera: Tenebrionidae) is an important worldwide secondary insect-pest of stored products that is observed among several commodities. This pest may cause considerable economical losses if not adequately controlled because it has a very high rate of population increase (Hill, 1990). The red flour beetle is a serious insect-pest species that attacks stored grain products such as flour, cereals, meal, beans and other dried food products; the larvae prefer cereal grain embryos. The female lays tiny white eggs (up to 450/female) that hatch after about 9 days (Sokokoff, 1972). 
The rice weevil Sitophilus oryzae (L.) (Coleoptera: Curculionidae) is a major main insect- pest of most stored cereal (rice, wheat, sorghum, barley and maize) worldwide before harvest and in store (Ahmed, 2001; Sabbour, 2012). The adults of the rice weevil are around $2 \mathrm{~mm}$ long with a long snout and able to fly. The body color appears to be dark brown, but on close examination, four orange/red spots are arranged in a cross on the wing covers (Halstead, 1964).

Synthetic insecticides such as lambda-cyhalothrin, primiphos-methyl and chlorpyrifos are currently of the main chemical that can be used to protect stored grains from insects. Spinosad is a new introduced and currently registered compound that can be used in several countries as a grain protectant.

The spinosyns are a unique family of fermentation-derived insecticides having potent activity and lower environmental effect. Spinosad is a defined combination of the two principal fermentation factors, spinosyns A and D. Structure-activity relationships (SARs) have been extensively studied, leading to development of a semisynthetic second-generation derivative, spinetoram. The spinosyns have a unique mechanism of action involving disruption of nicotinic acetylcholine receptors (Kirst, 2010). Spinosad possesses a unique mode of action in insects and controls insect strains resistant to other grain protectants. When launched globally, spinosad will represent a valuable new addition to the limited arsenal of grain protectants and can positively impact global food security. Its combination of high efficacy, broad insect pest spectrum, low mammalian toxicity, and sound environmental profile is unique among existing products currently used for storedgrain protection (Hertlein et al., 2011). Spinetoram is chemically similar to spinosad, a pesticide approved for use in organic agriculture with an established safety record. Spinetoram is a mixture of chemically modified spinosyns $\mathrm{J}$ and $\mathrm{L}$. Formulations are sold under various trade names Delegate ${ }^{\circledR}$, Exalt ${ }^{\circledR}$ and Radiant ${ }^{\circledR}$. Spinetoram is a broad-spectrum insecticide used to control crop-damaging insects. It shows high-efficacy against target insects at a very low use rate, with a margin of safety toward beneficial insects. It acts by causing persistent activation of insect nicotinic acetylcholine receptors (Anonymous, 2014). Spinetoram can be an effective alternative to spinosad, and may be used as a grain protectant.

The objective of this investigation is to evaluate the insecticidal activity of lambda-cyhalothrin, primiphos-methyl, chlorpyrifos and the new insecticide "spinetoram" against both the rust red flour beetle, Tribolium castaneum and the rice weevil Sitophilus oryzae.

\section{MATERIALS AND METHODS Tested insects}

Cultures of $S$. oryzae and $T$. castaneum were maintained in the laboratory without exposure to any insecticides on wheat grain and flour wheat, respectively, in glass jars containers kept under the conditions of $25^{\circ} \mathrm{C} \pm 3^{\circ} \mathrm{C}$ and $65 \pm 5 \% \mathrm{R}$.H., 
and continuous daily darkness of $24 \mathrm{hrs}$, except when working inside the rearing cabinet.

\section{Insecticides}

Four formulated insecticides (lambda- cyhalothrin [Lambada- Magic ${ }^{\circledR} 5 \%$ EC], primiphos- methyl [Actellic ${ }^{\circledR} 50 \%$ EC obtained from Shora Chemicals, Egypt], chlorpyrifos [Magic-phos ${ }^{\circledR} 48 \%$ EC] and spinetoram [Radiant ${ }^{\circledR} 12 \%$ C ] ) were tested. Each insecticide was diluted with water to obtain serial concentrations to be tested against the suggested insects.

\section{Bioassays}

The insecticidal activity of evaluated lambda-cyhalothrin, primiphose methyl, chlorpyrifos and spinetoram was determined by direct contact application. One millimeter of each diluted and prepared concentrations $(1 \mathrm{ml})$ was applied and regularly distributed on filter paper $(9 \mathrm{~cm}$ dia.). Each concentration was replicated 3 times. The filter papers were left over at room temperature to allow the water to evaporate and became dry. Each paper was handled carefully and fixed inside a Petri-dish. Ten adult insects were released into the filter paper and maintained in a Petri-dish that previously treated with the same concentration as that of the filter paper and left at constant room temperature along a period lasted for 72 hours. Mortality determination was done after 24, 48 and 72 hours. The insects were categorized to alive or dead (brittle and showing no movement over a $5 \mathrm{~min}$ observation period). This procedure would be easy and rapid method for evaluating the residual activity of a pesticide (Saad et al., 2011).

\section{Statistical Analysis of bioassays data}

Probit (mortality)/log con. (Dose) regression equations were calculated using the maximum likelihood algorithm described by Finney (1971) adopted as a computer program. Values of $\mathrm{LC}_{50}$ and $\mathrm{LC}_{95}$ 's and associated fiducial limits were also calculated by the method described by Finney. The correction of mortality percentages, if there were any control mortality was done using Abbott's formula (1925). Also, the relative efficiency (Toxicity index and Relative potency) of the tested compounds was determined by the formula of Sun (1950) as follows:

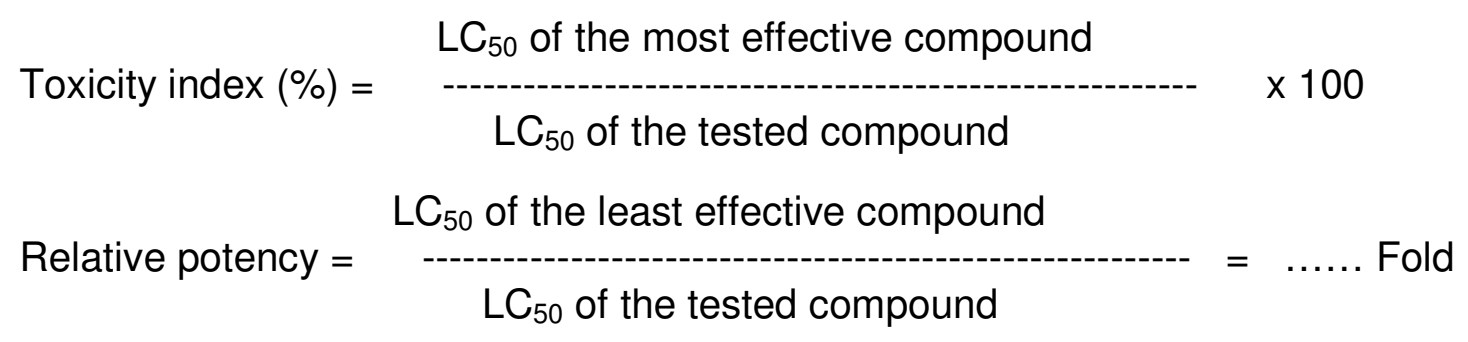




\section{RESULTS AND DISSCUSION}

\section{Efficacy of the tested insecticides against $T$. castaneum}

Data in Table 1 show the toxicity of different tested insecticides (lambdacyhalothrin [Lambada-Magic ${ }^{\circledR} 5 \%$ EC], primiphos-methyl $\left[\begin{array}{lll}\text { Actelli } & { }^{\oplus} 50 \% & E C\end{array}\right]$, chlorpyrifos [Magic-phos ${ }^{\circledR} 48 \% \mathrm{EC}$ ] and spinetoram [Radiant ${ }^{\circledR} 12 \% \mathrm{SC}$ ]) against $T$. castaneum after 24, 48 and 72 hours of exposure. Table 1 show the $\mathrm{LC}_{50}(\mathrm{ppm})$, fiducial limits, slope value and regression equation of each of these tested insecticides against Tribolium castaneum adults. After 24 hour of exposure, spinetoram was proved to be the most toxic insecticide tested against $T$. castaneum followed by chlorpyrifos, primiphos- methyl and lambda-cyhalothrin. Also, the same trend as that after $24 \mathrm{hrs}$ was achieved after $48 \mathrm{hrs}$ of exposure. Although lambda-cyhalothrin was shown to be the least toxic tested compound within the first $24 \mathrm{hrs}\left(\mathrm{LC}_{50}=86.29 \mathrm{ppm}\right)$, it was shown that after $72 \mathrm{hrs}$ of exposure that lambda-cyhalothrin was the most toxic compounds as compared with the other tested insecticides. The calculated $\mathrm{LC}_{50}$ of spinetoram was found to be $4.12 \mathrm{ppm}$ (Table 1).

From the previous results, it could be also seen that spinetoram was highly toxic against $T$. castaneum after 24 and 48 hrs of exposure. Vice -versa lambdacyhalothrin was highly toxic against $T$. castaneum followed by spinetoram; chlorpyrifos and primiphos-methyl after the exposure period of $72 \mathrm{hrs}$. Nevertheless, it could be noticed herein that the toxic effect of spinetoram $\left(\mathrm{LC}_{50}=4.12 \mathrm{ppm}\right)$ was merely equal to that of lambda-cyhalothrin $\left(\mathrm{LC}_{50}=3.28 \mathrm{ppm}\right)$ after that same period of $72 \mathrm{hrs}$ exposure.

Table (1): Response of $T$. castaneum to primiphos- methyl, lambda- cyhalothrin, chlorpyrifos and spinetoram

\begin{tabular}{|c|c|c|c|c|}
\hline $\begin{array}{l}\text { Bioassay } \\
\text { Time (hrs) }\end{array}$ & $\begin{array}{l}\mathrm{LC}_{50} \\
(\mathrm{ppm})\end{array}$ & $\begin{array}{l}\text { Fiducial limits } \\
\text { (ppm) } \\
\text { Lower-Upper }\end{array}$ & Slope & Regression Equation \\
\hline \multicolumn{5}{|c|}{ Primiphose methyl } \\
\hline 24 & 35.91 & $30.33-42.55$ & 2.12 & $Y=-3.29+2.12 x^{*}$ \\
\hline 48 & 22.93 & $19.47-26.99$ & 2.09 & $Y=-2.85+2.09 x$ \\
\hline 72 & 14.74 & $12.31-17.61$ & 2.39 & $Y=-2.80+2.39 x$ \\
\hline \multicolumn{5}{|c|}{ Lambde cyhalothrin } \\
\hline 24 & 86.29 & $41.99-190.36$ & 0.63 & $Y=-1.22+0.63 x$ \\
\hline 48 & 16.78 & $8.99-31.33$ & 0.52 & $Y=-0.64+0.52 x$ \\
\hline 72 & 3.28 & $1.45-6.71$ & 0.58 & $Y=-0.30+0.58 x$ \\
\hline \multicolumn{5}{|c|}{ Chlorpyrifos } \\
\hline 24 & 23.99 & $20.55-27.99$ & 2.29 & $Y=-3.15+2.29 x$ \\
\hline 48 & 14.63 & $11.94-17.89$ & 2.08 & $Y=-2.42+2.08 x$ \\
\hline 72 & 8.55 & $6.43-11.30$ & 2.09 & $Y=-1.95+2.09 x$ \\
\hline \multicolumn{5}{|c|}{ Spinetoram } \\
\hline 24 & 18.64 & $14.56-23.80$ & 1.47 & $Y=-1.87+1.47 x$ \\
\hline 48 & 9.49 & $7.05-12.68$ & 1.28 & $Y=-1.25+1.28$ \\
\hline 72 & 4.12 & $2.89-5.78$ & 1.24 & $Y=-0.76+1.24 x$ \\
\hline
\end{tabular}


These results supported the obtained results by Huang and Subramanyam (2003) who reported that spinosad at 0.5 or $1 \mathrm{mg} / \mathrm{kg}$ on white wheat was very effective against all the tested species except the red and confused flour beetle $T$. confusum). Also, Arthur (1992) mentioned that Sitophilus zeamais or Tribolium castaneum did not survive in the case of the application of deltamethrin + chlorpyrifos to corn. Meanwile, results of Khashaveh et al. (2008) revealed that the application of spinosad dust formulation at higher rates and for longer exposure intervals could control $T$. castaneum in different oilseed types.

Denloye et al. (2008) reported that both Sumithion ${ }^{\circledR}$ (fenitrothion) and Actellic $^{\circledR}$ (primiphos-methyl) were effective for controlling C. maculatus and $S$. zeamais at concentrations higher than that of $5 \mathrm{mg} / \mathrm{kg}$ which have been recommended by manufacturers.

Table 2 shows the $\mathrm{LC}_{50}$ (ppm), Toxicity index (\%) and Relative potency (fold) of the four tested insecticides against the rust red flour beetle adults ( $T$. castaneum) after 24, 48 and 72 hours.

Table (2): $\mathrm{LC}_{50}$ values, Toxicity index and Relative potency of the tested insecticides against $T$. castaneum adults (after 24, 48 and 72 hrs bioassay)

\begin{tabular}{lccc}
\hline \multicolumn{1}{c}{ Treatment } & $\begin{array}{c}\text { Calculated LC } \\
\text { (ppm) }\end{array}$ & Toxicity index \% & $\begin{array}{c}\text { Relative potency } \\
\text { (fold) }\end{array}$ \\
\hline \multicolumn{2}{c}{ After $\mathbf{2 4}$ hrs } \\
\hline Primiphos-methyl & 35.91 & 51.91 & 2.40 \\
Lambade-cyhalothrin & 86.29 & 21.60 & 1.00 \\
Chlorpyrifos & 23.99 & 77.70 & 3.60 \\
Spinetoram & 18.64 & 100.00 & 4.63 \\
\hline \multicolumn{4}{c}{ After $\mathbf{4 8}$ hrs } \\
Primiphos-methyl & 22.93 & 41.39 & 1.00 \\
Lambade-cyhalothrin & 16.78 & 56.55 & 1.37 \\
Chlorpyrifos & 14.63 & 64.87 & 1.57 \\
Spinetoram & 9.49 & 100.00 & 2.42 \\
\hline & After $\mathbf{7 2}$ hrs & 1.00 \\
\hline Primiphos-methyl & 14.74 & 22.25 & 4.49 \\
Lambade-cyhalothrin & 3.28 & 100.00 & 1.72 \\
Chlorpyrifos & 8.55 & 38.36 & 3.58 \\
Spinetoram & 4.12 & 79.61 & \\
\hline
\end{tabular}

After $24 \mathrm{hrs}$ bioassay, it was confirmed that lambde-cyhalothrin was the least efficient toxicant $\left(\mathrm{LC}_{50}=86.29\right.$ with toxicity index equal to $21.6 \%$ and relative potency of $1.001 \mathrm{fold}$, respectively). After $48 \mathrm{hrs}$, spinetoram still had a strong 
action on $T$. castaneum $\left(\mathrm{LC}_{50}=9.49 \mathrm{ppm}\right.$, toxicity index $100 \%$ and relative potency 2.42 fold), followed by chlorpyrifos ( $\mathrm{LC}_{50}=14.63 \mathrm{ppm}$, toxicity index $64.87 \%$ and relative potency 1.57 fold). Primiphos-methyl was the lowest efficient toxicant ( $\mathrm{LC}_{50}$ $=22.93 \mathrm{ppm}$ with a toxicity index of $41.39 \%$ (of spinetoram) and relative potency of 1.00 fold). After $72 \mathrm{hrs}$, each of spinetoram and lambde-cyhalothrin gave strong action on $T$. castaneum represented by their high toxicity and reduced $\mathrm{LC}_{50}$ values (Toxicity index of $79.61 \& 100 \%$ and relative potency of $3.58 \& 4.49$ folds, respectively.)

\section{Efficacy of the tested insecticides against S. oryzae}

Table 3 shows the extracted parameters of the toxicity of different tested concentrations of evaluated insecticides expressed as the $\mathrm{LC}_{50}$ value (ppm), fiducial limits, slope value and regression equation of each of these tested insecticides against Sitophilus oryzae adults after 24, 48 and 72 hours of exposure. After $24 \mathrm{hrs}$ of exposure, chlorpyrifos and spinetoram were equally high toxic against $S$. oryzae adults showing merely the same $L_{50}$ values of 14.56 and 13.38ppm, respectively.

Again, the further exposure of the adults of the rice weevil $S$. oryzae to the tested insecticides up to 48 and 72 hrs revealed that chlorpyrifos was as toxic as spinetoram and comparatively were more toxic and superior to the other tested compounds ( $\mathrm{LC}_{50}=5.73$ and $5.29 \mathrm{ppm}$, respectively) after a $72 \mathrm{hrs}$ bioassay versus lambda-cyhalothrin which was the least toxic compound (40.62ppm). Moreover, chlorpyrifos was as toxic as spinetoram.

From the previous results, it could be concluded that spinetoram was the utmost highly toxic insecticide against $S$. oryzae followed by chlorpyrifos, and primiphos-methyl after 24 and 48hrs. Also spinetoram was the superior and highly toxic one against $S$. oryzae, followed by chlorpyrifos, lambda-cyhalothrin and primiphos-methyl after $72 \mathrm{hrs}$.

Samson and Parker (1988) found that deltamethrin was not effective against Sitophilus spp. Our results agree with those results reported by Kljajic et al. (2007) who found that the most toxic insecticides to $S$. oryzae adults were bifenthrin and dichlorvos, and the least toxic was pirimiphos-methyl. Also, Getchell and Subramanyam (2008) reported on the comparison of the time required for killing 50\% ( $\left.\mathrm{LT}_{50}\right)$ and 95\% ( $\left.\mathrm{LT}_{95}\right)$ and showed that $R$. dominica adults were consistently and significantly more susceptible and died quickly than $S$. oryzae adults when exposed to spinosad treated commodities.

Kavallieratos et al. (2010) stated that the lowest dose of spinosad was highly effective (>90\%) against $R$. dominica and $S$. oryzae. In the case of $T$. confusum combination of longer exposures with higher doses was required for each formulation to be effective. Our results disagree with those arrived at by Rumbos et al. (2013) who found that Sitophilus species were highly susceptible to two pirimiphos-methyl formulations, since complete mortality $(100 \%)$ was achieved 
while the present investigation showed that $S$. oryzae was more susceptible to spinetoram and chlorpyrifos.

Table (3): Response of Sitophilus oryzae to primiphos-methyl, lambde cyhalothrin, chlorpyrifos and spinetoram

\begin{tabular}{|c|c|c|c|c|}
\hline $\begin{array}{l}\text { Bioassay } \\
\text { time (hrs) }\end{array}$ & $\begin{array}{l}\text { LC }_{50} \\
(\mathrm{ppm})\end{array}$ & $\begin{array}{c}\text { Fiducial limits } \\
\text { (ppm) } \\
\text { Lower-Upper }\end{array}$ & Slope & $\begin{array}{c}\text { Regression } \\
\text { Equation }\end{array}$ \\
\hline \multicolumn{5}{|c|}{ Primiphos- methyl } \\
\hline 24 & 35.05 & $29.13-42.22$ & 1.90 & $Y=-2.94+1.90 x^{*}$ \\
\hline 48 & 21.73 & $18.19-25.95$ & 1.93 & $Y=-2.58+1.93 x$ \\
\hline 72 & 14.13 & $11.64-17.12$ & 2.25 & $Y=-2.59+2.25 x$ \\
\hline \multicolumn{5}{|c|}{ Lambda- cyhalothrin } \\
\hline 24 & 82.04 & $47.59-146.01$ & 0.85 & $Y=-1.63+0.85 x$ \\
\hline 48 & 40.62 & $27.22-61.44$ & 0.90 & $Y=-1.46+0.90 x$ \\
\hline 72 & 9.86 & $6.34-15.05$ & 0.82 & $Y=-0.81+0.82 x$ \\
\hline \multicolumn{5}{|c|}{ Chlorpyrifos } \\
\hline 24 & 17.09 & $14.56-20.04$ & 2.52 & $Y=-3.10+2.52 x$ \\
\hline 48 & 9.96 & $7.67-12.87$ & 2.06 & $Y=-2.06+2.06 x$ \\
\hline 72 & 5.73 & $3.95-8.24$ & 2.12 & $Y=-1.61+2.12 x$ \\
\hline \multicolumn{5}{|c|}{ Spinetoram } \\
\hline 24 & 17.22 & $13.38-22.09$ & 1.50 & $Y=-1.86+1.50 x$ \\
\hline 48 & 9.33 & $7.14-12.09$ & 1.53 & $Y=-1.48+1.53 x$ \\
\hline 72 & 5.29 & $3.99-6.94$ & 1.61 & $Y=-1.17+1.61 x$ \\
\hline
\end{tabular}

The exhibited results in Table 4 show the calculated values of $\mathrm{LC}_{50}(\mathrm{ppm})$, Toxicity index (\%) and Relative potency (fold) of the four tested insecticides against the rice weevil adults S. oryzae after 24, 48 and 72 hours. After 24 hrs, chlorpyrifos had the strongest action against $S$. oryzae $\left(\mathrm{LC}_{50}=17.09 \mathrm{ppm}\right.$ with a toxicity index of $100 \%$ and relative potency of 4.80 fold). Spinetoram was as effective as chlorpyrifos $\mathrm{LC}_{50}=17.22 \mathrm{ppm}$ with a toxicity index of $99.24 \%$ and relative potency of 4.76 fold) followed by primiphos-methyl $\left(\mathrm{LC}_{50}=35.05 \mathrm{ppm}\right.$ with toxicity index equal to $48.76 \%$ and relative potency of 4.27 fold). Lambde-cyhalothrin was the lowest efficient toxicant $\left(\mathrm{LC}_{50}=82.04\right.$ with toxicity index equal to 20.83 and relative potency of 1.00 fold). After $48 \mathrm{hrs}$ of exposure, spinetoram had a strong action on S. oryzae $\left(\mathrm{LC}_{50}=9.33 \mathrm{ppm}\right.$ with toxicity index of $100 \%$ and relative potency of 4.35 fold), while lambde-cyhalothrin was still the lowest efficient toxicant ( $\mathrm{LC}_{50}=40.62$ ppm, with toxicity index of $22.97 \%$ and relative potency of 1.00 fold). Furthermore, after 72 hrs, spinetoram had a strong action against $S$. oryzae showing its high toxicity $\left(\mathrm{LC}_{50}=5.29 \mathrm{ppm}\right.$ with a toxicity index of $100 \%$ and relative potency of 2.67 fold). On the other hand, primiphos-methyl was the lowest efficient toxicant $\left(\mathrm{LC}_{50}=\right.$ 14.13 ppm with toxicity index $37.44 \%$ and a standard relative potency considered for the least efficient compound that equal 1.00). 
Table (4): LC $_{50}$ values, Toxicity index and Relative potency of the tested insecticides against $S$. oryzae adults (after 24, 48 and $72 \mathrm{hrs}$ bioassay).

\begin{tabular}{|c|c|c|c|}
\hline Treatment & $\begin{array}{l}\text { Calculated } L C_{50} \\
\quad(p p m)\end{array}$ & $\begin{array}{l}\text { Toxicity index } \\
(\%)\end{array}$ & $\begin{array}{l}\text { Relative potency } \\
\text { (fold) }\end{array}$ \\
\hline \multicolumn{4}{|c|}{ After 24 hrs } \\
\hline Primiphos- methyl & 35.05 & 48.76 & 2.34 \\
\hline Lambde-cyhalothrin & 82.04 & 20.83 & 1.00 \\
\hline Chlorpyrifos & 17.09 & 100.00 & 4.80 \\
\hline Spinetoram & 17.22 & 99.24 & 4.76 \\
\hline \multicolumn{4}{|c|}{ After 48 hrs } \\
\hline Primiphos- methyl & 21.73 & 42.94 & 1.87 \\
\hline Lambde-cyhalothrin & 40.62 & 22.97 & 1.00 \\
\hline Chlorpyrifos & 9.96 & 93.67 & 4.08 \\
\hline Spinetoram & 9.33 & 100.00 & 4.35 \\
\hline \multicolumn{4}{|c|}{ After $72 \mathrm{hrs}$} \\
\hline Primiphos- methyl & 14.13 & 37.44 & 1.00 \\
\hline Lambde-cyhalothrin & 9.86 & 53.65 & 1.43 \\
\hline Chlorpyrifos & 5.73 & 92.32 & 2.47 \\
\hline Spinetoram & 5.29 & 100.00 & 2.67 \\
\hline
\end{tabular}

From the afore-mentioned results, it could be revealed that the spinosyns having potent activity, lower environmental effect and unique mode of action toward insects and can control insect strains resistant to other grain protectants (malathion, chlorpyrifos ...etc). Therefore, the application of spinetoram would be realty valuable as a good protectant against stored-grain insect-pests. Though, its application could be recommended and involved within integrated stored-product pest management programs for protecting grain stores from the insect infestation.

\section{REFERENCES:}

Abbott, W. S. (1925). A method of computing the effectiveness of an insecticide. J. Econ. Entomol., 18:265-267.

Ahmed, M. (2001). Disinfestation of stored grains, pulses, dried fruits and nuts, and other dried foods. In: Food Irradiation: Principles and Applications. Molins, R. (Ed.), John Wiley \& Sons, New York, 77-112.

Anonymous (2014). Dow Product Safety Assessment: Spinetoram. The Dow Chemical Company.pp.6

Arthur, F. H. (1992). Efficacy of unsynergised deltamethrin and deltamethrin + chlorpyrifos-methyl combinations as protectants of stored wheat and stored corn (maize). J. Stored Prod. Res., 30(1): 87-94.

Denloye, A. A., K. O. Tesilim, H. Negbenebor and W. A. Makanjuola (2008). Assessment of the efficacy of actellic and sumithion in protecting grains from insect infestation during storage. J. Ent., 5 (1): $24-30$. 
Finney, D. J. (1971). Probit analysis. $3^{\text {rd }}$ ed., Cambridge Univ. Press., London and New York. pp.318.

Getchell, A. I. and B. Subramanyam (2008). Immediate and delayed mortality of Rhyzopertha dominica (Coleoptera: Bostrichidae) and Sitophilus oryzae (Coleoptera: Curculionidae) adults exposed to spinosad- treated commodities. J. Econ. Entomol., 101(3): 1022-1027.

Halstead, D. G. H. (1964). The separation of Sitophilus oryzae (L.) and S. zeamais Motschulsky (Col., Curculionidae), with a summary of their distribution. Entomol. Mon. Mag., 99:72-74.

Hertlein, M.B., G. D. Thompson, B. Subramanyam and C. G. Athanassiou (2011). Spinosad: A new natural product for stored grain protection (Review). J. Stored Prod. Res., 47(3):131-146.

Hill, D. S. (1990). Pests of stored products and their control. Belhaven Press, London. pp. 274.

Huang, F. and B. Subramanyam (2003). Efficacy of spinosad against several stored - product insects on hard white winter wheat. The 2003 ESA Annual Meeting and Exhibition (Abstract No. DO 430).

Kavallieratos, N. G., C. G. Athanassiou., B. J. Vayias., S. Kotzamanidis and S. D. Synodis (2010). Efficacy and adherence ratio of diatomaceous earth and spinosad in three wheat varieties against three stored-product insect pests. J. Stored Prod. Res., 46(2): 73-80.

Khashaveh, A., M. Ziaee., M. H. Safaralizadeh and F. A. Lorestani (2008). Control of Tribolium castaneum (Herbst) (Coleoptera: Tenebrionidae) with spinosad dust formulation in different oilseeds. Turk. J. Agric., 33: 203-209.

Kljajic, P., G. Andric and I. Peric (2007). Effects of several contact insecticides on adults of three Sitophilus species. $9^{\text {th }}$ International Working Conference on Stored Product Protection: 338-343.

Krist , H. A. (2010). The spinosyn family of insecticides: realizing the potential of natural products research. J. Antibiotics, 63: 101-111.

Madrid, F. J., N. D. G. White and S. R. Loschiavo (1990). Insects in stored cereals and their association with farming practices in southern Manitoba. Canad. Entomolo., 122: 515-523.

Mohan, S. and P. G. Fields (2002).A simple technique to assess compounds that are repellents or attractive to stored-products insects. J. Stored Prod. Res., 33: 289-298.

Rumbos, C. I., A. C. Dutton and C. G. Athanassiou (2013). Comparison of two pirimiphos-methyl formulations against major stored-product insect species. J. Stored Prod. Res., 55: 106-115.

Sabbour, M.M. (2012). Entomotoxicity assay of two nanoparticle materials $\left(\mathrm{Al}_{2} \mathrm{O}_{3}\right.$ and $\left.\mathrm{TiO}_{2}\right)$ against Sitophilus oryzae under laboratory and store conditions in Egypt.J. Nov. Appl. Sci., 1: 103-108.

Saad, A. S. A., A. E. Omar, E. H. M. Tayeb and A. A. A. ElQadasi (2011). Synergistic effect of Sylgard $309^{\circledR}$ with prepared and commercial formulations of malathion and chlorpyrifos against Tribolium castaneum (Coleoptera: Tenebrionidae). J. Adv. Agric. Res., 16 (3):505-525. 
Samson, P. R. and R. J. Parker (1988). Laboratory studies on protectants for control of Coleoptera in maize. J. Stored Prod. Res., 25(1): 49-55.

Sokoloff, A. (1972). The biology of Tribolium, with special emphasis on genetic aspects. Vol. 1. Oxford University Press, London, 300 pp.

Sun, Y. P. (1950). Toxicity indexes: an improved method of comparing the relative toxicity of insecticides. J. Econ. Entomol., 43:45-53.

$$
\text { الملخص العربي }
$$

\section{كفاءة بعض المبيدات في حماية المخازن من الإصابة بحشرات المواد المخزونة}

عبدالفتاح سيد عبدالكريم سعد ، السيا حسن محمد تايب ، عثمان أحمد زغلول ،

$$
\text { أبويكر عبدالغني الصغير عبدالغني }
$$

قسم وقاية النبات - كلية الزراعة (سابا باشا) - جامعة الإسكندرية - ص • ب اسب إب بولكلي - الإسكندرية جمهورية مصر العربية

تعتبر مبيدات الآفات أداة رخيصة نسبياً وسهلة الإستخدام لمكافحة حشرات المواد المخزونة التي تهاجم مخازن الحبوب ومطاحن الدقيق والأعلاف. مما بمكن من إستخدام بعض المبيدات ذات التأثير المنخفض علي الثذييات لرشها في المخازن قبل أو أثثاء عملية التخزين وذلك بغرض الحماية الوقائية من الآفات الحشرية أو مكافحة الحشرات الموجودة

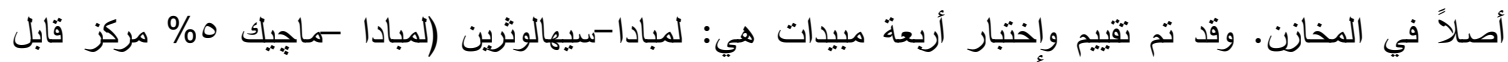

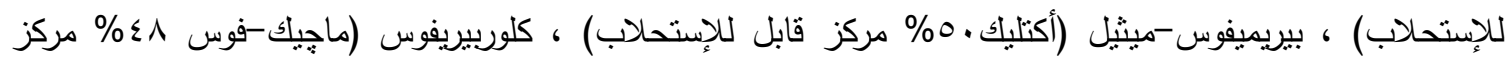

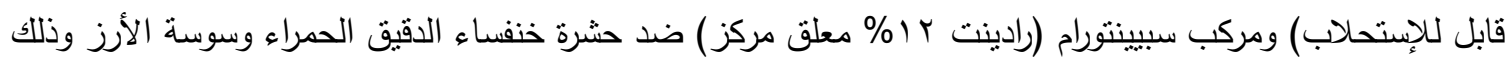

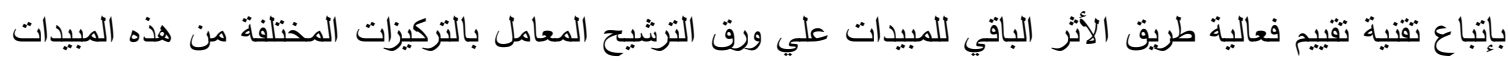

أظهرت النتائج أن تأثثر وإستجابة الحشرات المعرضة للمبيدات تختلف بإختلاف المبيد المختبر ونوع الحشرة

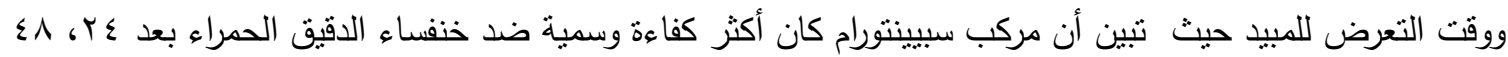

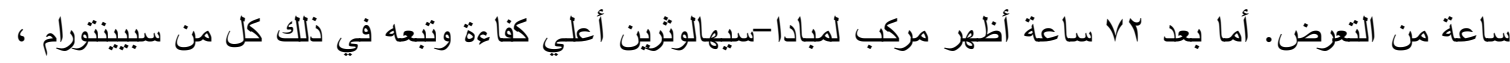
كلوربيريفوس ثم بيريميفوس- ميثيل ـ وفي هذا الصدد يمكن ملاحظة أن التاثير السام لمركب سبيينتورام كان لحد كبير

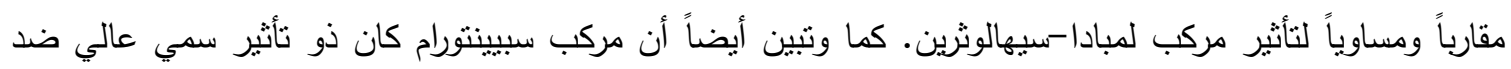

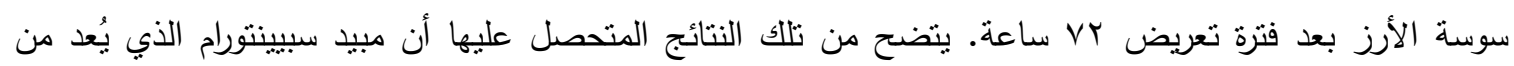

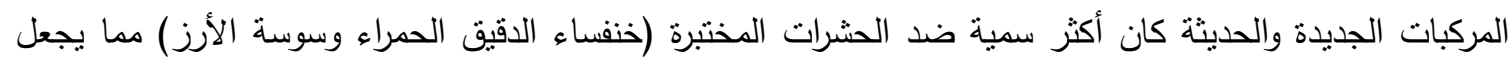

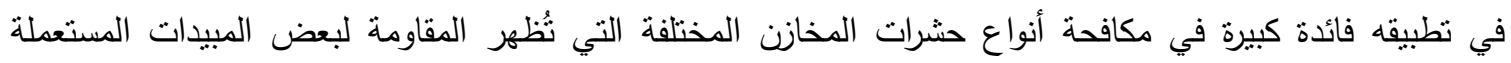

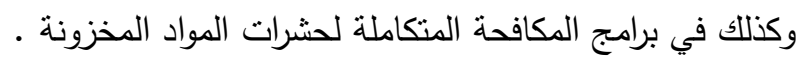

